\title{
Flexible Learning: A New Learning Design in this Time of COVID-19 Pandemic
}

\author{
${ }^{1}$ Ezekiel O. Pelayo, ${ }^{2}$ Leizl O. Pelayo \\ ${ }^{1}$ Department of Mathematics and Natural Sciences, Surigao Del Sur State University, Tandag City, Philippines \\ ${ }^{2}$ Surigao Del Sur State University-Cagwait Campus, Cagwait, Surigao del Sur, Philippines
}

\begin{abstract}
Learning has tremendously taken place, and consideration in all academic institutions, for it stipulates knowledge, behavior, skills, values, or preferences and may involve analyzing different types of information. In particular, flexible learning provides learners with privilege and choices about where, when, and how learning occurs. In this time of the pandemic, the quality of education must be given prioritization; its transfer must always be given importance despite the barriers and hindrances. With this, flexible learning has shown us a broad-brimmed view that it will relieve the current academic situation. Hence, the ultimate objective of this study was to evaluate whether flexible learning helps to promote the continuous delivery of education or not in teaching the course GE-MMW (Mathematics in the Modern World) in BSBA(Bachelor of Science in Business Administration) students of Surigao Del Sur State University, Tandag City, Philippines. The researcher used an interview method and prepared a flexible learning schedule as part of the data collection process. The researcher then gathered all the information and provided a thorough analysis. The results then show that the engagement of flexible learning as a new learning design helps in the teaching and learning process.
\end{abstract}

Keywords:- Flexible learning, Learning Design, COVID19 Pandemic.

\section{INTRODUCTION}

If one has to look closely at the contemporary problem of how to raise the quality of education, no matter what the discipline is, it manifests that the answer lies in the right educational objectives at one end, effective transfer of knowledge at the other, with instructional procedures and materials in between. With the current situation due to the COVID19 pandemic, it dramatically alternates the learning situation in many countries and one of these is the Philippines. Face-to-face contact learning has change immediately to online learning at home. Since the growth of positive cases in the country, the national government has implemented policy for learning and work from home. Many universities including Surigao Del Sur State University which are not fully engaged in conducting online lectures are constrained to do online distance lectures and avoid face-to-face systems. With this, the engagement of flexible learning has clamored in the new normal education set up. Less face to face, distant learning or e-learning are among the inclusions of the alternative design of learning. Hence, it was with the utmost interest of the researcher to address the situation in the academe due to today's pandemic battle.

Internationally, the educator sector is undergoing a paradigm shift that encompasses both innovative built learning environments and significant reform of the pedagogical core (Prain et al, 2012) to better prepare students across all curriculum areas and learning stages to succeed in a rapidly changing and interconnected world. An array of learning environments are emerging across educational institutions as educators strive to adapt their teaching practices and enhance learning outcomes. Flexible learning contains a variety of furniture options in a relatively open space, which can be configured in various ways to facilitate a range of teaching and learning experiences.

According to Shuville et al. (2008) "Flexible learning is a set of educational philosophies and systems, concerned with providing learners with increased choice, convenience, and personalization to suit the learner. In particular, flexible learning provides learners with choices about where, when, and how learning occurs". In this matter, learners will experience connectivism, constructivism, and engagement (Simens, 2005; Ling and Fraser 2014, Marshall 2007).

It is acknowledged that flexible learning inherently supports educators to employ student-centered teaching approaches (Mulcahy, 2016), and that these spaces can accommodate and facilitate learning modes such as collaboration, explicit instruction, independent work, feedback and reflection as well as experiential learning, which are believed to lead to improvements in students' engagement and motivation (Ryan, 2001). It is broadly assumed that the teaching and learning approach used in flexible learning will ultimately lead to improvements in academic outcomes.

Because of the occurrence of the COVID 19 pandemic that we are experiencing nowadays, educators have realized that students entering the classroom for face to face class discussions are in danger. Today's students are demanding change in the educational set up. Teachers are encouraged to engage and come up with new strategies to fit in this current situation in education sector. Such as the use of interactive software, digital imaging, audio and video creation tools, computers, and web 2.0 tools. The challenging job is to choose which tool to use and how to secure the quality of education in this new normal mode. 


\section{Significance of this study}

This paper emphasized the significance of flexible learning as a new learning design in this time of health crisis. As we have noticed, nowadays, a high percentage of students are benefiting from online learning. Many students are joining in online courses and it helps to utilize technology fully. The new learning design could serve as a new learning environment where students can learn at their own time, place, and pace. This paper has crafted as a basis that flexible learning can serve as a reinforcement to the new normal mode of education and hence the present paper was needed for this situation.

\section{On Flexible Learning}

Learning is a process where the transfer of knowledge takes place. Different types of learning designs were introduced for the purpose of providing aid in the learning process and one of these is flexible learning. According to Lundin (2014), flexible learning is an idealized state where there is a mixture of education philosophy, pedagogical strategies, delivery modalities, and administrative structures which allows students to choose according to their learning needs, styles and circumstances. In principle, flexible learning approachces may be applied to any subject; still, accurate analysis of the demands of the learner and of the practicality of this approach is highly recommended.

Flexible learning approaches are often designed using a full range of teaching and learning theories, philosophies, and methods to provide students with opportunities to access information and expertise, contribute ideas and opinions, and correspond with other learners and mentors.

\section{$>$ On Learning Design}

Learning design refers to a framework that supports learning experiences. It pertains to deliberate choices about what, when, where, and how to teach. To support learning, decisions about the content, structure, timing, pedagogical strategies, sequences of learning activities, and the type and frequency of assessment in the course, as well as the nature of technology were used . Recently the concept of "Learning Design" has gained momentum in the education space, mostly through discussions at conferences, webinars, ebooks, and more.

\section{Dn COVID19 Pandemic}

The coronavirus COVID19 pandemic is the defining global health crisis of our time and the greatest challenge we have faced since then. Since its emergence in Asia late last year, the virus has spread to every continent except Antartica. But the pandemic is much more than a health crisis, its also an unprecedent socio-economic crisis. Stressing every one of the countries it touches, it has the potential to create devastating social, economic and political effects that will leave deep and longstanding scars (UNDP, 2020).

The pandemic has caused global social and economic disruption, including the largest global recession since the great depression and global famines affecting 265 million people. It has led to the postponement or cancellation of sporting, religious, political, and cultural events, widespread supply shortages exacerbated by panic buying, and decreased emissions of pollutants and greenhouse gases. Schools, universities, and colleges have been closed either on a nationwide or local basis in 161 countries, affecting approximately 98.6 percent of the world's student population.

\section{METHOD USED IN THE PRESENT STUDY}

This paper helped to distinguish the state of flexible learning as a new learning design in the teaching-learning process to continue the delivery of quality education. With this, the author employed a quantitative descriptive study using the interview method to accomplish the study. The researcher has looked and visited many websites which that provided relevant literature and results in flexible learning. The researcher has prepared a schedule for flexible learning and collected responses from the students about their perception of flexible learning and other learning design. These are the students who were taking the subject GE-MMW (Mathematics in the Modern World) with a total population of 86. Regarding the instrument used and its validity for data collection, it was tested from a previous study that used the same construct that verified the construct validity (Roy, 2013). After gathering the information, the researcher then made required analysis, basic statistical techniques were utilized during the treatment and gave interpretation, conclusions, and recommendations related to the result.

\section{$>$ Objectives}

The primal aim of this study was to find out that flexible learning helps to promote continuous delivery of quality education, especially in this time of the pandemic. Wherein, this study was guided with the following questions;

1. What learning design do students like to engage in the subject?

2. What is the academic achievement among the students who are interested in flexible learning and other learning design?

\section{Population and Sample}

The population of this study was the students who were studying GE-MMW(General Education-Mathematics in the Modern World) subject in the College of Business and Management, Surigao Del Sur State University, Tandag City, Philippines. A total sample of 86 students in which belong to two intact classes were selected by the researcher, these students are currently undergraduate taking the degree of BSBA-FM (Bachelor of Science in Business Administration Major in Financial Management). This study was conducted within the period of March to May, S.Y 2020, this was the time of the emergence, and rapid growth of COVID19 cases in the Philippines, and quarantine prescriptions has imposed. 


\section{RESULTS AND DISCUSSION}

\begin{tabular}{|c|c|c|}
\hline $\begin{array}{c}\text { What learning design do you like } \\
\text { to use for the subject? }\end{array}$ & $\mathbf{N}$ & Percentage(\%) \\
\hline Flexible Learning & 58 & 67.44 \\
\hline Other Learning & 28 & 32.56 \\
\hline Total & 86 & 100 \\
\hline
\end{tabular}

Table 1:- Students' preferred learning design
As reflected in table 1, it is evident that $67.44 \%$ of students were interested to utilize flexible learning as new learning design, while $32.56 \%$ of the population were responded not interested in flexible learning and preferred other learning design. By looking and analyzing the data, the researchers found out that more students are willing to engage in flexible learning design, but some of them are not and has other preference. The data also indicates that the use of other learning designs in response to the present situation is significant for it aids the possible gaps due to the pandemic.

\begin{tabular}{|c|c|c|c|c|c|}
\hline $\begin{array}{c}\text { Final } \\
\text { Examinati } \\
\text { on Grade }\end{array}$ & $\begin{array}{c}\text { Adjectival } \\
\text { Rating }\end{array}$ & $\begin{array}{c}\text { No. Of Student } \\
\text { Interested in } \\
\text { flexible learning }\end{array}$ & $\begin{array}{c}\text { No. Of Student not } \\
\text { Interested in flexible } \\
\text { learning(other learning) }\end{array}$ & $\begin{array}{c}\text { Percentage(\%) Of } \\
\text { Student Interested } \\
\text { in flexible learning }\end{array}$ & $\begin{array}{c}\text { Percentage(\%) Of } \\
\text { Student not Interested } \\
\text { in flexible learning }\end{array}$ \\
\hline $1.0-1.2$ & Excellent & 15 & 3 & 25.86 & 10.71 \\
\hline $1.3-1.5$ & $\begin{array}{c}\text { Very } \\
\text { Satisfactory }\end{array}$ & 35 & 15 & 60.34 & 53.57 \\
\hline $1.6-2.0$ & Satisfactory & 8 & 10 & 13.79 & 35.71 \\
\hline $2.1-2.5$ & Good & 0 & 0 & 0 & 0 \\
\hline $2.6 .-3.0$ & Fair & 0 & 0 & 0 & 0 \\
\hline Total & & 58 & 28 & 100 & 100 \\
\hline
\end{tabular}

Table 2:- Academic achievement among the students who are interested in flexible learning and other learning design.

Table 2 reflected the academic achievement among the students in their marks in the final examination, data shows that $25.86 \%$ of the students got a grade mark between 1.0-1.5 in flexible learning and $10.71 \%$ of students gained the same mark in other learning design with corresponding adjectival rating as Excellent. $60.34 \%$ of students in flexible learning obtained a grade marks between 1.3-1.5 and $53.57 \%$ of students not in favor of flexible learning obtained the same grade mark with an adjectival rating of Very Satisfactory. Another $13.79 \%$ of students in favor for flexible learning have a grade mark between $1.6-2.0$, while $35.71 \%$ of the students not in favor for flexible learning obtained a grade mark between 2.1-2.5 with corresponding adjectival rating as Satisfactory.

By looking and analyzing the data, it is distinct that students who choose flexible learning have shown remarkable performance in their final examination results than other students who chose other learning design. Hence, the outcome conveys that the engagement of flexible learning in today's situation will help the continuous delivery of the lessons and will not sacrifice the quality of education.

\section{CONCLUSIONS}

Flexible learning assists the learners in planning their activities according to their needs, interest, and ebullience. It helps the learner's mind be pleasant and away from fear. With this, the study provides us the idea that students should become conscious in engaging themselves with flexible learning, so that they can come out with the positive results. Students must see to it that they are equipped with knowledge of technology for them to make learning easy and effective. Hence, based on the result of the study this concludes that flexible learning helps promote the continuous delivery of quality education, especially in this time of health crisis.

\section{RECOMMENDATIONS}

In today's generation, technology has penetrated its roots deeply into every aspect, especially in the field of education. Wherein, technology is now becoming essential in all its applications wherein it gives us comfort and safety away from the COVID19 Pandemic. Hence, the researcher warmly recommends the following; school administrators should facilitate/conduct enhancement training for teachers for them to have high proficiency and skill of technology, the academic institutions must exert effort to provide adequate infrastructure to establish flexible learning specifically internet facilities, teachers can utilize technology-based teaching methods especially in today's situation and lastly, the academic institutions are encouraged to engage and treat flexible learning as a part of the new normal education.

\section{REFERENCES}

[1]. Joan, R. (2013), Flexible learning as a new learning design in classroom process to promote quality education, I-managers Journal on Social Educational Technology, Vol.9.

[2]. Jonassen D., \& Land S. Theoretical foundations of learning environment. $2^{\text {nd }}$ ed.. Abingdon: Routledge; 2012.

[3]. Karlippanon KE, Cliff DP, Lancaster SL, Okely AD, Parrish AM. Perceived interplay between flexible learning spaces and teaching, learning and student wellbeing. Learn Environment Res. 2018; 21(3):301-20.

[4]. Kuhlthau C. Guided Inquiry: Learning in the $21^{\text {st }}$ Century. In Center for International Scholarship in School Libraries (CISSL), Rutgers University, USA; 2015. p. 1-8. 
[5]. Lim, D.H (2012), The effect of flexible learning schedule on online learners' learning, application, and instructional perception.

[6]. Ling, P. and Fraser, K. (2014), "Pedagogies for Next Generation Learning Spaces: Theory, Context, Action", The Future of Learning and Teaching in the Next Generation Learning Spaces (International Perspectives on Higher Education Research, Vol. 12), Emerald Group Publishing.

[7]. Lundin, R. (2014). "Flexible teaching and learning:Perspectives and practices."p.6, retrived from: https://sydney.edu.au/science/uniserve_science/newsle tter/vol13/lundin.html

[8]. Mulcahy D. Policy matters: de/re/territorialising spaces of learning in Victorian governement schools. J Educ Policy. 2016; 31(1):81-97

[9]. Nadeak, B. (2020), The effectivenessof distance learning using social media during the pandemic period of COVID19: A case in Universitas Kristen Indonesia, International Journal of Advanced Science and Technology, Vol.29, No. 7, (2020).pp.1764-1772

[10]. Organization for Economic Co-operation and Development. The OECD handbook for Innovative Learnjng Environments. 2017

[11]. Prain V., Cox., Deed C., Edwards D., Farrelly C., Keeffe M. Chracterising personalised learning. In: Prain V., editor. Personalising learning in open-plan schools. 2015.

[12]. Ryan AM, Patrick H. the Classroom Social Environment and Changes in Adolescents' Motivation and Engagement During Middle School. Am Educ Res J. 2001;38(2):437-60.

[13]. Salandanan, G.G. (2005). Teaching and the teacher. Lorimar Publishing Company Inc.

[14]. Shurville, S., O'Grady, T., and Mayall,P. (2008). Educational and institutional flexibility of Australian Educational Software. Campus-Wide Information Systems, Emerald Group Publishing Limited, 25(2), 74-84. 